\title{
Development of Learning by doing Governance Model Industry based on Vocational Middle School in Makassar
}

\author{
Muhammad Nur Abdullah ${ }^{1}$,Arifin Ahmad ${ }^{2}$, Hamsu Abdul Gani ${ }^{3}$ \\ ${ }^{12}$ Department of Educational Science, Universitas Negeri Makassar \\ Makassar, Indonesia \\ Email: muh.nurabdullah26 [AT] gmail.com \\ ${ }^{3}$ Department of Engineering, Universitas Negeri Makassar \\ Makassar, Indonesia \\ Email: arifin_unm [AT] yahoo.co.id \\ ${ }^{1}$ Department of Engineering, Universitas Cokroaminoto Makassar \\ Makassar, Indonesia \\ Email: hamsuabdulgani [AT] yahoo.com
}

\begin{abstract}
Vocational High School (SMK) is one of the education systems in Indonesia which is expected to be able to deliver the young generation to have knowledge, skills and competencies. One way to do this is by implementing Industrial Work Practices (prakerin). The development of the IB-LeDo model is one of the more systematic, targeted and measurable models of prakerin implementation. The objectives of the study were to find out: 1) An overview of the current IB-LeDo governance model in Vocational Schools, 2) Development of a valid, practical and attractive IB-LeDo governance model, and 3) Knowing the effectiveness of the model. This study uses Research and Development research and ADDIE models. This research was conducted for students who carry out internship in Makassar. The research subjects were 15 people. The data analysis model used is; preliminary stage, development stage, and evaluation stage. The analysis is assessed by experts including; validity, practicality The results of research and development can be concluded, among others: 1) the IB-LeDo governance model has improved through the concept of maximum management, increased parental attention, increased mentors/supervisors, systematic and measurable prakerin assessment methods and increased character values, 2) The developed IB-LeDo model meets the requirements of validity, practicality, and interest, and 3) The results of the effectiveness test show that there is a significant increase in knowledge and competence before and after participating in the internship., and attractiveness, as well as test effectiveness based on the results of the application of the model.
\end{abstract}

Keywords_ - Learning by Doing Governance Model, Vocational High School, and Industry

\section{INTRODUCTION}

Vocational High School (SMK) is a type of secondary education that specifically prepares graduates to become skilled workers and are ready to enter the wider community. Vocational education is an educational institution that prepares students who are interested in being educated to become workers in certain fields in accordance with the demands of the world of work. According to [1] the ultimate goal of the vocational education curriculum is not only measured through achievement in the form of grades but through the results of these achievements, namely results in the form of performance in the world of work. Thus, the vocational education curriculum is process-oriented (in the form of experiences and activities in the school environment) and product (the effect of these experiences and activities on graduates) [2]. In carrying out its duties and functions, it is proven that SMK has a strategic role in employment education [3]. The slogan "SMK certainly can (Ready to Work, Smart, and Competitive)" is intended that SMK graduates are expected to be able to compete in the world of work and at least be able to produce their own jobs with the knowledge and skills they have. The vocational education paradigm is very different from general education. Vocational education emphasizes education that adapts to market demand (demand driven). Continuity between users of education graduates and education providers as well as compatibility between employees and employers are the basis for organizing and measuring the success of implementing vocational education.

Effective vocational education is education that can produce graduate competencies (students) that are in accordance with the requirements of certain fields of work/world of work.

In fact, current SMK graduates are still not able to answer the labor problems needed by the world of work. 
There are still many job opportunities offered by the job market that have not been filled [4], because existing education graduates are not absorbed in the job market.

Vocational education must be integrated with the company indicates the need for an active role for companies, whether industry or business, as well as the community as users of vocational education. Its importance is to acquaint students with the real work required in subsequent work. The development of vocational education in the socio-economic context is government economic education that refers to the needs of the labor market and economic development [5]; [6], to prepare students to enter employment (Hiniker \& Putnam in [7]. Must always be closer to the world of work [8]; Hiniker \& Putnam in [7]). Its development is based on community and job needs [8]. Vocational education students need programs that reveal skills, knowledge, work attitudes, experiences, insights, and networks that are in accordance with the training they are engaged in [7].

The problem that is felt to be very important is related to the inability of graduates to enter the workforce. This is because the quality of graduates is far from the market's will, this is in line with the complaints of industrial business actors in South Sulawesi who complain that students who graduate from SMK do not have work standardization competencies. Besides that, there is also a mismatch between the "supply"/offer of graduates and the small "demand", there are still many SMK graduates who have not been fully absorbed in the industrial world, because the application capabilities of graduates are not in accordance with work needs. Large national and even international scale industries exist in Makassar, but still this has not been able to answer the existing problems, not many SMK graduates in Makassar are absorbed in the industry, not to mention the Employability Skills they face after working in the industry. In addition, from the results of initial interviews with several SMK alumni who are currently working in one of the industries in Makassar, information is obtained that the obstacles they often face in industry are fields of work that sometimes have never been found in school so that it becomes a burden when faced with these problems.

Learning by doing is a concept of the relationship between the world of education and the world of work. One form of embodiment of the concept referred to in Vocational High Schools (SMK) is the implementation of Dual System Education (dual systems) through industrial work practices (Prakerin) but even then, it is not optimal. In implementing Prakerin, obstacles are felt by both parties (schools and industry). it is not balanced with the diversity of the surrounding industry. Furthermore, the obstacles felt by the industry include: (1) there is no stable structure of positions and expertise, especially in small and medium industries, (2) there is no budget allocation plan for education development, (3) there is no perception of profit. PSG for industry, and (4) lack of awareness about increasing effectiveness, efficiency, and quality in the implementation of training in industry [2].

According to [8], the problems faced in an effort to make reforms in the field of vocational education both conceptually, program improvements and operations. One of the conceptual problems is the wide gap between the school world and the industrial world. This results in a mismatch between SMK graduates and the needs of the workforce in the industry. In the implementation of the program, the problem with the content of the learning program is that it is still oriented to the teaching of subjects, not to the expertise that is in accordance with the needs of the world of work. Meanwhile, at the operational level, the process of assessing learning outcomes in vocational schools does not yet refer to work quality standards in the industry. Meanwhile, according to the research results of Sonhadji, et al. (1997) in [9], the implementation of PSG faces obstacles, including the following: (1) the delegation of tasks and responsibilities among the organizational apparatus of the Pokja PSG is not evenly distributed, and there is a dominant tendency in the Pokja Chair, (2) the supervising teacher has not functioned optimally. in industry, and some of them are not relevant to their field, (3) difficulty in collaborating with partner institutions that are classified as medium and large, (4) low management of student training management by industry, especially in small industries, (5) instructors in industry many do not meet the requirements and have not played an effective role, (6) there are still many students who are looking for industrial training sites themselves, (7) the lack of time provided by the School Council to coordinate, (8) the length of processing permits and applications for training, (9) lack of discipline and low awareness of students towards work safety, and (10) the imbalance between the number of vocational schools and the world's number a business/industry. From the above findings it can be stated that the implementation of PSG has so far experienced structural, geographical, technological, psychological, academic, managerial, and cultural potential constraints so that the PSG concept in this case Prakerin needs support for effective governance that is able to synergize school components. and other supporters, especially the local industry, so that the implementation of Industrial Work Practices (Prakerin) truly achieves the goal of Learning by doing. Therefore, the author is strongly encouraged to raise this issue in a dissertation study with the title "Development of an Industry-Based Learning by Doing Governance Model in Vocational High Schools" with the hope of providing a solution to the achievement of learning by doing objectives with competency skills and good employability through the concept of good governance. manage learning by doing well and synergize with the existing industrial potential in Makassar.

Based on the above background, the formulation of the problem in this research is how the current governance of learning by doing is, how is the validity, practicality and attractiveness of the industry-based learning by doing governance model and how effective the industry-based learning by doing governance model is. 


\section{LITERATURE REVIEW}

\subsection{Learning by Doing Program}

One of the good steps to meet the demands of development is to direct the development of human resources to education and development of intellectual abilities that create a scientific community, which is aware of and able to implement the principles of achieving the highest efficiency, productivity, and quality. Active learning by Dewey's theory in [10] which applies the principles of "learning by doing", namely that students need to be involved in the learning process spontaneously. From the students' ignorance of things, they do not know, it encourages their active involvement in a learning process. Active learning contains various useful tips to foster active learning abilities in students and explore the potential of students and teachers to develop together and share knowledge, skills and experiences. In Indonesian the sentence "learning by doing" is defined as "learning by doing". Learning by doing means that we prioritize acting over theorizing. People who do something that he did not know before and because he did it, he came to know, that is called "learning by doing". It should be noted that the learning by doing process, which focuses on trying to learn while doing work/activities with real examples, deserves to be implemented through proper, careful, systematic and structured planning so that it produces optimal results and does not interfere but instead encourages students to continue to be enthusiastic, creative and take the initiative in doing the work involved.

With the learning by doing program, all parties including the government, educational institutions, and the industrial/business world are involved and coordinated in the entire system according to their respective positions and roles. the program is a vehicle for building partnerships with industry in setting priorities and substance for vocational education. The implementation of the learning by doing program also requires harmony between the preparation of the workforce produced by vocational education and the needs of the workforce. As revealed by [11] that vocational high schools can develop their ability to work in institutional partnerships with the business world and industry in a mutually beneficial and synergistic manner, so that they are always relevant to future trends as well as financially. One indicator of the implementation of learning by doing between education and development needs is the balance between the supply of labor by education and job opportunities in the economic system. If an educated workforce can be utilized optimally, education can be said to be commensurate with the needs of the world of work on a macro basis. By borrowing the concept of modern industrial system management thinking, the management of vocational education in Indonesia should view the education process as a continuous educational process improvement, which starts from a series of cycles since the ideas to produce quality graduates (outputs). , curriculum development, learning process, to take responsibility for satisfying users of vocational education graduates. Furthermore, based on information as feedback collected from graduate users (external customers), creative ideas can be developed to redesign the curriculum or improve the current vocational education process.

The concept of learning by doing / learning and teaching "learning by doing" between the world of education and the world of work pioneered by John Dewey by Doing needs to be revived. This concept can reduce the number of unemployed SMK graduates which is increasing day by day. Running learning by doing is not a simple thing. Therefore, ideally, there are three components that must move simultaneously to make the learning by doing program a success, namely schools, the world of work (companies) and the government. Of the three components, the role of the school is the most important requirement. The creativity and intelligence of school administrators are the determining factors for the success or failure of the program, as well as its relevance to development needs in general and the needs of the world of work, business and industry in particular. Some of the principles that will be used as a learning by doing program strategy include the implementation of Dual System Education (PSG). Dual System Education (PSG) is basically a form of providing professional skills education that combines systematically and harmonized education programs in schools and mastery of skills programs obtained through direct work activities in the world of work, and is directed towards achieving a certain level of professional expertise. In essence, PSG is a strategy that brings students closer to the world of work and this is a proactive strategy that demands changes in attitudes and mindsets as well as the functions of education actors at the vocational level, society and the business/industry world in responding to these changing dynamics.

Industrial Work Practices (Prakerin), Industrial Attachment Training (IAT), interships, traineeships, industrial experience, apprenticeships, teaching factories (Production Units) at SMK are terms that are often used in almost all areas of expertise in SMK: (1) SMK Teknologi and Engineering; (2) Information and Communication Technology Vocational School; (3) Health Vocational School; (4) Agribusiness and Agrotechnology Vocational Schools; (5) Fisheries and Marine Vocational School; (6) Business and Management Vocational School; (7) Tourism Vocational School; (8) Visual Arts and Crafts Vocational School, and (9) Performing Arts Vocational School. The term Prakerin has become a standard term used in Technology and Engineering Vocational Schools so that in this study, this term will be put forward. Prakerin is part of the dual system education (PSG) as a joint program between SMK and industry that is implemented in the business/industry world. In the SMK curriculum [12] it is stated that: Prakerin is a pattern of organizing training and education that is managed jointly between Vocational Schools and industry/professional associations as partner institutions, starting from the planning, implementation to evaluation and certification stages which are a unified program using various alternative forms of implementation, such as day releases, block releases and so on. Prakerin is a component of the practice of professional skills, in the form of programmatic activities in real situations to achieve the level of expertise and professional 
work attitudes carried out in the industry. Learning in the world of work (industry) is an integral part of the overall training program, therefore the material studied and the competencies being trained must be clearly related to the competency profile of graduates that have been determined. The education and training program is prepared and implemented jointly and responsibly between schools and industry, and is supported by the Chamber of Commerce and Industry (KADIN) representing industry and community leaders representing the general public. Furthermore, in the Dikmendikti Prakerin Act, it is stated that prakerin is a mandatory program that must be carried out by schools, especially vocational high schools and education outside of school and must be followed by students. The implementation of industrial work practices will help students to strengthen the learning outcomes obtained at school and provide students with real experience in accordance with the chosen study program. From these statements, in this study, internship is defined as the implementation of education that integrates educational activities (theory) in schools with educational activities (practices) in the industrial world. In other words, internship is strategy for student experience in learning process through direct work (learning by doing) on the real job. Learners gain experience with work materials and familiarize themselves with new developments.

According to [13], what is meant by the research and development model is "a process used to develop and validate educational products". Sometimes this research is also called research-based development which appears as a strategy and aims to improve the quality of education, Research and Development also aims to discover new knowledge through basic research or to answer specific questions about practical problems. through applied research which is used to improve educational practices. In this study, an industry-based learning by doing governance model called the IB-LeDo Model will be developed. The outline of the components of the IB-LeDo Model is described, among others: Management Stages; The management stages of the proposed IB-LeDo Model are as follows. Phase I: Designing (Planning); Phase II: Organizing; Phase III: Implementation/Direction (Actuating); and Phase IV: Monitoring/Assessment (Controlling). This IB-LeDo model has characteristics that distinguish it from the previous model, namely: At the planning stage, the following are: 1) mapping of competencies and employability skills required by industry, and 2) mapping of competencies and talents of students who will carry out PSG; At the organizing stage, what was done were: given guidance for supervisors and job descriptions for school supervisors and industry supervisors; At the implementation stage, what is carried out are: 1) industry class before students enter the industry and when students are in the industry, and 2) an Industry Pocket Book (BSI) is prepared which contains basic material related to industrial competencies needed by students. At the monitoring/assessment stage, what is carried out are: 1) periodic monitoring of the industry is also carried out monitoring competence where students visit supervisor educators, 2) as a reference for competency monitoring, a book on Industrial Competency Requirements is prepared which contains the following points: competency points in the industry to check their achievement. The IB-LeDo model developed, there is interaction between students, between educators and students, between industrial supervisors and students, and also between educators and supervisors in industry. In this IB-LeDo Model, an active interaction and reaction system is created because in practice students are required to actively carry out work practices in the industry by not forgetting the competencies they must know, all of which will be checked for implementation through the SKI book, students will be more active in communicate with supervisors in industry and supervisor educators because monitoring is carried out more intensively. For the IB-LeDo Model, a support system is needed, namely: (a) competency mapping observation sheets and industrial employability skills and mapping of students' talents and competencies, (b) PSG/Prakerin implementation guidelines, which contain the contents of the implementation stages starting from planning to assessment. , including job descriptions for supervisors, (c) Industry Pocket Book (BSI) which contains: implementation rules, training schedule and brief materials related to required industrial competencies, and (d). the Industrial Competency Requirements monitoring book (SKI) contains the points of industrial competence required with a check column for implementation by supervisors and supervisors in the industry. The instructional impacts for this developed model are as follows: The instructional impact of the IB-LeDo model is to increase the mastery of learning by doing governance, especially in the implementation of industrial work practices that focus on industrial potential in the region with an emphasis on the existing industrial base in the local area in planning, implementation, monitoring and evaluation so that optimal implementation results are achieved, and the accompanying impact of the IBLeDo model is the inculcation of employability skills values in industry and industrial work climate through work practices.

\section{RESEARCH METHOD}

\subsection{Research Design}

The type of research carried out is Research and Development (R\&D) research. Development of an industry-based learning by doing governance model for SMK by referring to the [13] and ADDIE models. Research and development Research and Development can be defined as a process or steps to develop a new product or improve an existing product, which can be accounted for. The product does not have to be in the form of objects or hardware (hardware), such as books, modules, learning aids in the classroom or in the laboratory, but can also be software (Software) such as computer programs [14]. According to [14] are: preliminary studies, model development trials and final product tests and dissemination of results. These research and development steps will also be combined with the research and development model of [15] 
where the first step in the development stage of [15] is: the research carried out can depart from the potential and problems. The [13] model and [15] development model, because the model to be developed departs from the potential. The intended potential is the existence of competence, employability skills, and character values in the industry, as well as the problems faced in developing these potentials in the implementation of learning by doing.

The development of this model can also clearly determine the competencies to be achieved from the implementation of industrial work practices (prakerin) and determine the management concept that supports the achievement of industrial competencies and employability skills as well as character development in its implementation. However, the achievement of these competencies is based on the existing structure of the SMK curriculum majoring in electrical power installation engineering, then combined with competencies in the form of knowledge, understanding or skills (industrial competence) that can be developed in industry, as well as employability skills and character values in industry. Research and development stages or procedures include: 1 . potential analysis stage (mapping of industrial competencies, employability skills and character values), problem analysis and needs analysis; 2 . model design stage; 3 . model development stage; 4. implementation stage; and 5. evaluation stage.

This research was carried out in Makassar, a survey/preliminary study (need assessment) in the form of competency mapping according to the SMK curriculum and industrial competence, employability skills and character values that can be developed, problem analysis and needs analysis carried out in technology and engineering SMK in Makassar. Prakerin was carried out by SMK Gunung Sari Makassar at PLN Makassar with 15 participants as research subjects.

The stages or procedures for developing the IB-LeDo model will follow the design of the [13] and ADDIE models combined with the development steps of [15] which consist of five stages, namely: 1 . Need Assessment stage; 2 . model design stage; 3. model development stage; 4. implementation stage; and 5. evaluation stage.

\section{RESULTS AND DISCUSSION}

Based on the results obtained from expert validation of the developed model and instruments that will be used in the further development research process, it can be concluded that the validation results of the models and instruments can be seen in the following table:

Table 1. Recapitulation of the results of the validation of the IB-LeDo model and research instruments

\begin{tabular}{|c|c|c|c|}
\hline No & Assessment Aspect & $\%$ & Category \\
\hline 1 & Model of rating sheet & 90.47 & Very Valid \\
\hline 2 & Model of Implementation Observation Sheet & 92.64 & Very Valid \\
\hline 3 & Prakerin Management Observation Sheet & 90.00 & Very Valid \\
\hline 4 & $\begin{array}{c}\text { Questionnaire of participants' responses to the } \\
\text { application of the model }\end{array}$ & 91.96 & Very Valid \\
\hline 5 & Participant/group activity observation sheet & 90.62 & Very Valid \\
\hline & Total & 455.69 & \\
\hline & Average $(152+126+108+103+58) / 150$ & 3.64 & Very High \\
\hline & Reliability $(1+2+3+4+5) / 5$ & \multicolumn{2}{|c|}{$0.88 \geq 0.75$} \\
\hline & Average & 91.13 & Very Valid \\
\hline
\end{tabular}

Based on table 1 above, the results obtained from the validation of all experts on the developed model and the instruments to be used in the further development research process, it can be concluded that the validation results of the models and instruments in general have an average rating of 3.64 which means the level of validity is very high. high because it is in the range of values from 3.5 to 4.00 with a mean percentage of 91.13 percent including the very valid criteria because it is in the interval 86 percent to 100 percent [16].

Table 2. Recapitulation of Supervisor/Instructor Response Results to the IB-LeDo Model

\begin{tabular}{|c|c|c|c|}
\hline No & Respondent & $\%$ & Category \\
\hline 1 & Instructor 1 & 97.61 & Practicality Very good \\
\hline 2 & Instructor 2 & 96.42 & Practicality Very good \\
\hline \multirow[t]{4}{*}{3} & Instructor 3 & 94.04 & Practicality Very good \\
\hline & Total & 288.07 & \\
\hline & Average & 3.84 & Very High \\
\hline & Percentage & 96.02 & Very Good \\
\hline
\end{tabular}


Based on the data in table 2 above, it can be concluded that the practicality of the IB-LeDo model based on the supervisor/instructor response shows an average of 3.84 which means high, this means that the clarity of each stage and model device so that it can be accepted as feasible. and interesting for supervisors/instructors with an average supervisor/instructor response of 96.02 percent, this means that the level of practicality is very good according to the interval value of 85 percent -100 percent [17].

Table 3. Recapitulation of data on student responses to the implementation of prakerin using the IB-LeDo model

\begin{tabular}{|c|c|c|c|c|}
\hline No & Assessment Aspect & Total & $\%$ & Category \\
\hline 1 & Model Stages & 323 & 89.72 & Very Good \\
\hline 2 & Instructor Role & 221 & 92.08 & Very Good \\
\hline \multirow[t]{2}{*}{3} & Auxiliary Media/ Model Device & 220 & 91.66 & Very Good \\
\hline & Total & 764 & & \\
\hline
\end{tabular}

According to table 3 above, it can be concluded that the response of students to the prakerin stage carried out by applying the IB-LeDo governance model showed an average score of 90.95 percent. Based on the practicality criteria, the participant's response to the implementation of internship with the application of the IB-LeDo model in the practical category is very good, which lies in the interval of 85 percent -100 percent [17].

Table 4. Observation data on the implementation of the IBP-LeDo model

\begin{tabular}{|c|c|c|c|c|c|}
\hline \multirow[t]{2}{*}{ IB-LeDo Model } & \multirow{2}{*}{$\begin{array}{c}\text { Rating } \\
\text { Point }\end{array}$} & \multicolumn{2}{|c|}{$\begin{array}{c}\text { Observation } \\
\text { Result } \\
\end{array}$} & \multirow[t]{2}{*}{$\boldsymbol{F}$} & \multirow[t]{2}{*}{$\%$} \\
\hline & & $P 1$ & $P 2$ & & \\
\hline \multirow{7}{*}{ Planning Stage } & 1 & 2 & 2 & 4 & 100 \\
\hline & 2 & 2 & 2 & 4 & 100 \\
\hline & 3 & 2 & 2 & 4 & 100 \\
\hline & 4 & 1 & 2 & 3 & 75 \\
\hline & 5 & 2 & 1 & 3 & 75 \\
\hline & 6 & 2 & 2 & 4 & 100 \\
\hline & 7 & 2 & 1 & 3 & 75 \\
\hline Total & & & & & \multirow{2}{*}{89.28} \\
\hline Average & & 1. & & & \\
\hline \multirow{2}{*}{ Organizing Stage } & 1 & 2 & 2 & 4 & 100 \\
\hline & 2 & 2 & 2 & 4 & 100 \\
\hline Total & & & & & \multirow{2}{*}{100} \\
\hline Average & & & & & \\
\hline \multirow{3}{*}{ Implementation Stage } & 1 & 2 & 2 & 4 & 100 \\
\hline & 2 & 2 & 2 & 4 & 100 \\
\hline & 3 & 2 & 2 & 4 & 100 \\
\hline Total & & & & & \multirow{2}{*}{100} \\
\hline Average & & & & & \\
\hline \multirow{5}{*}{ Monitoring and evaluation stage } & 1 & 2 & 1 & 3 & 75 \\
\hline & 2 & 2 & 2 & 4 & 100 \\
\hline & 3 & 2 & 2 & 4 & 100 \\
\hline & 4 & 2 & 1 & 3 & 75 \\
\hline & 5 & 1 & 2 & 3 & 75 \\
\hline Total & & & & & \multirow{2}{*}{85} \\
\hline Average & \multicolumn{4}{|c|}{1.7} & \\
\hline $\begin{array}{l}\text { Overall Average } \\
\quad(1+2+3+4)\end{array}$ & \multicolumn{4}{|c|}{1.87} & 91.17 \\
\hline
\end{tabular}

The data in table 4 above shows that the implementation of the IB-LeDo prakerin governance model based on observations from observers during the internship is in the very good practicality category, namely 91.17 percent because it lies in the 85 percent -100 percent interval [17] and when referring to the criteria for implementing the model, the IB- 
LeDo training model is fully implemented, with an average of 1.87 being at 1.5 FR 2, meaning that it is fully implemented modification by [18].

Table 5. Observation data on the ability of the supervising teacher/instructor to manage the IB-LeDo model

\begin{tabular}{|c|c|c|c|c|c|}
\hline \multirow[t]{2}{*}{ IB-LeDo Model } & \multirow{2}{*}{$\begin{array}{c}\text { Rating } \\
\text { Point }\end{array}$} & \multicolumn{2}{|c|}{$\begin{array}{c}\text { Observation } \\
\text { Result }\end{array}$} & \multirow[t]{2}{*}{$\boldsymbol{F}$} & \multirow[t]{2}{*}{$\%$} \\
\hline & & $P 1$ & $P 2$ & & \\
\hline \multirow{7}{*}{ Planning Stage } & 1 & 4 & 4 & 8 & 100 \\
\hline & 2 & 4 & 4 & 8 & 100 \\
\hline & 3 & 4 & 4 & 8 & 100 \\
\hline & 4 & 3 & 4 & 7 & 87.5 \\
\hline & 5 & 3 & 4 & 7 & 87.5 \\
\hline & 6 & 4 & 4 & 8 & 100 \\
\hline & 7 & 4 & 4 & 8 & 100 \\
\hline Total & \multicolumn{4}{|c|}{54} & \multirow{2}{*}{96.42} \\
\hline Average & & & & & \\
\hline \multirow[t]{2}{*}{ Organizing Stage } & 1 & 4 & 4 & 8 & 100 \\
\hline & 2 & 4 & 4 & 8 & 100 \\
\hline Total & \multicolumn{4}{|c|}{16} & \multirow{2}{*}{100} \\
\hline Average & & & & & \\
\hline \multirow{2}{*}{ Implementation Stage } & 1 & 4 & 4 & 8 & 100 \\
\hline & 2 & 3 & 4 & 7 & 87.5 \\
\hline Total & & & & & \multirow{2}{*}{93.75} \\
\hline Average & & & & & \\
\hline \multirow{4}{*}{ Monitoring and evaluation stage } & 1 & 4 & 3 & 7 & 87.5 \\
\hline & 2 & 4 & 3 & 7 & 87.5 \\
\hline & 3 & 3 & 4 & 7 & 87.5 \\
\hline & 4 & 4 & 3 & 7 & 87.5 \\
\hline Total & & & & & \multirow{2}{*}{87.5} \\
\hline Average & \multicolumn{4}{|c|}{3.5} & \\
\hline $\begin{array}{l}\text { Overall Average } \\
\quad(1+2+3+4)\end{array}$ & \multicolumn{4}{|c|}{3.77} & 94.17 \\
\hline
\end{tabular}

The data in table 5 shows that 94.17 percent of supervising teachers/instructors carry out the stages in the governance of the IB-LeDo model of prakerin. If it is associated with practicality criteria, then the ability of supervising teachers and instructors in managing the implementation of the IB-LeDo model prakerin is in the very good practicality category because it lies in the 85 percent -100 percent interval [17].

Table 6. Recapitulation of the results of observations of the IB-LeDo . model internship participants

\begin{tabular}{|c|c|c|c|c|}
\hline$N O$ & Observer & $F$ & $\%$ & Description \\
\hline 1 & Observer 1 & 849 & 88.43 & \\
\hline 2 & Observer 2 & 860 & 89.58 & \\
\hline \multirow[t]{2}{*}{3} & Observer 3 & 860 & 89.58 & \\
\hline & Average & & 89.19 & \\
\hline
\end{tabular}

The results of data analysis in table 6 above show that based on the results of observers from all observers, the average is 89.19 percent. This means that in terms of the practicality of the model that has been developed which is measured by the activeness of students following a series of stages in the implementation of internships, it is in the very high category, meaning that the practicality is very good.

Table 7. Recapitulation of data analysis of student responses to the attractiveness of the IB-LeDo model

\begin{tabular}{|c|c|c|c|c|}
\hline \multirow[t]{2}{*}{ Assessment Aspect } & \multicolumn{3}{|c|}{$\begin{array}{c}\text { Total Value of All Questionnaires in Each } \\
\text { Main Assessment Item }\end{array}$} & \multirow{2}{*}{$\begin{array}{l}\text { Percentage } \\
(\%)\end{array}$} \\
\hline & 1 & 2 & 3 & \\
\hline $\begin{array}{c}\text { All prakerin } \\
\text { participants as many as } \\
15 \text { people }\end{array}$ & 323 & 221 & 220 & 90,95 \\
\hline
\end{tabular}


Based on table 7 above, the attractiveness data for the IB-LeDo internship model that has been developed based on the student responses shows a value with a percentage of 90.95 percent, so it can be concluded that the overall stages of the IB-LeDo internship model and the model devices developed, the attractiveness category is very good. This is based on the acquisition of the response value which is in the 86 percent -100 percent value interval [16].

Table 8. T-Test Average Value of Pre-Test and Post-Test of Students' Industrial Competence (Paired Samples Test)

\begin{tabular}{|c|c|c|c|c|c|c|c|c|c|}
\hline \multicolumn{7}{|c|}{ Paired Differences } & \multirow{3}{*}{$T$} & \multirow{3}{*}{$D f$} & \multirow{3}{*}{$\begin{array}{l}\text { Sig. }(2- \\
\text { tailed })\end{array}$} \\
\hline \multirow{2}{*}{\multicolumn{2}{|c|}{ Variance }} & \multirow[t]{2}{*}{ Mean } & \multirow[t]{2}{*}{$\begin{array}{c}\text { Std. } \\
\text { Deviation }\end{array}$} & \multirow[t]{2}{*}{$\begin{array}{l}\text { Std. } \\
\text { Error } \\
\text { Mean }\end{array}$} & \multicolumn{2}{|c|}{$\begin{array}{l}95 \% \text { Confidence } \\
\text { Interval of the } \\
\text { Difference }\end{array}$} & & & \\
\hline & & & & & Lower & Upper & & & \\
\hline$\frac{\pi}{2}$ & $\begin{array}{c}\text { Pre-Test } \\
\text { dan Post- } \\
\text { Test }\end{array}$ & -46.667 & 1.953 & .357 & -47.396 & -45.937 & 130.845 & 29 & .000 \\
\hline
\end{tabular}

Based on table 8 above, the results of the paired mean test (T-Test) show that the average difference between the pretest (before treatment) and post-test (after treatment) scores is $-46,667$. The minus sign (-) means that the student's skill/industrial competency value after being treated using the IB-LeDo model product is greater than the student's skill/industrial competency value before the learning treatment. This means that there is an increase in the value of students expertise/industrial competence after being given treatment with an average deviation of increase spread across the entire sample of 1.953. Furthermore, on the average test results, the value of tcount $=130.845>$ ttable $=2.445$ at the level of $=$ 0.05 , and the probability value $(\rho)$ Sig. $=0.000<=0.05$. This means rejecting Ho and concluding that in the population from which the sample was taken there is a statistically significant difference between the average value of the industrial competence of students before and after treatment (Application of the IB-LeDo Model). The results of descriptive data analysis through the distribution of the industrial competency values of students before and after the application of the model which is strengthened by the results of the T-test analysis through the normality test and homogeneity test, in general the industrial-based learning by doing governance model as outlined in the IB model Prakerin implementation -The developed LeDo is effective in increasing the industrial knowledge/competency of prakerin students.

\section{CONCLUSION}

Based on the results of the research data analysis, it can be concluded, among others: 1) The Learning by Doing governance model that has been implemented so far in vocational high schools, especially in the fields of technology and engineering, tends not to go through the basic concepts of optimal management, lack of briefing and organization that involves industry, lack of attention from parents of students regarding the implementation of prakerin, lack of teachers/supervisors/instructors in productive (vocational) fields of study to guide students, and the absence of supervisory guidebooks and systematic and measurable prakerin assessment methods to see competency improvement and character development in the implementation of prakerin, 2) The IB-LeDo model is declared valid by experts and practitioners. After testing the IB-LeDo model, it was declared practical and very interesting, this can be seen from the implementation of almost all aspects of the model, responses from supervisors/instructors and students who stated that practicality was good, and an assessment of the appearance of the model's appearance, based on the needs and conditions in the industry in participating in the training, model devices and more. Responded very well and stated very interesting. The IB-LeDo Learning by Doing (Prakerin) governance model that has been developed meets the criteria of validity, reliability, practicality, is attractive and has practicality and is easy to implement and the results are accountable (accountable), 3) The IB-LeDo model is declared effective, seen from the increasing industrial competence of students. Therefore, the goal of obtaining a quality IB-LeDo model has been achieved. In addition, the implementation of the IB-LeDo model presents an accompanying impact, namely the development of employability skills and character values for students, such as; obedience to the rules, piety with perseverance in carrying out worship, responsibility, earnest in work, honest, good cooperation and so on. 


\section{REFERENCES}

1. C. R. Finch and J. R. Crunkilton, Curriculum Development in Vocational and Technical Education. Planning, Content, and Implementation, 5th Ed. Boston, MA: Allyn and Bacon, 1999.

2. Direktoral Jenderal Pendidikan Vokasi, Rencana Strategis Direktorat Jenderal Pendidikan VOkasi Tahun 2020-2024. Jakarta: Direktoral Jenderal Pendidikan Vokasi, 2020. Accessed: Sep. 06, 2021. [Online]. Available: https://www.vokasi.kemdikbud.go.id/storage/document/July2021/xTNFJ7ifzGNjC8OFi9er.pdf

3. Kementerian Pendidikan dan Kebudayaan Indonesia, Rencana Strategis: Kementerian Pendidikan dan Kebudayaan 2020-2024. Jakarta: Kementerian Pendidikan dan Kebudayaan Indonesia, 2020. Accessed: Sep. 06, 2021. [Online]. Available: https://dikti.kemdikbud.go.id/wp-content/uploads/2020/10/RENSTRA-KEMENDIKBUD-full-version.pdf

4. Soenaryo and D. Supriadi, Sejarah pendidikan teknik dan kejuruan di Indonesia: membangun manusia produkif. Jakarta: Departemen Pendidikan Nasional, Direktorat Jenderal Pendidikan Dasar dan Menengah, Direktorat Pendidikan Menengah Kejuruan, 2002.

5. Singh, "Social and Cultural Aspects of Informal Sector Learning: Meeting the Goals of EFA," in International Handbook of Education for the Changing World of Work: Bridging Academic and Vocational Learning, R. Maclean and D. Wilson, Eds. Dordrecht: Springer Netherlands, 2009, pp. 349-358. doi: 10.1007/978-1-4020-5281-1_23.

6. M. Pavlova, Technology and Vocational Education for Sustainable Development, 1st Ed. Netherlands: Springer Netherlands, 2009.

7. R. Maclean and D. Wilson, International Handbook of Education for the Changing World of Work. Netherlands: Springer Netherlands, 2009.

8. D. Wardiman, Pengembangan Sumber Daya Manusia: Melalui Sekolah Kejuruan (SMK). Jakarta: Jayakarta Agung Offset, 1998.

9. J. Maknun, "The Implementation of Generative Learning Model on Physics Lesson to Increase Mastery Concepts and Generic Science Skills of Vocational Students," American Journal of Educational Research, vol. 3, no. 6, Art. no. 6, May 2015, doi: 10.12691/education-3-6-12.

10. A. Suharyanto, "Teori John Dewey dalam Psikologi Pendidikan," DosenPsikologi.com, Feb. 06, 2019. https://dosenpsikologi.com/teori-john-dewey-dalam-psikologi-pendidikan (accessed Sep. 03, 2020).

11. H. Wiratama, Sejarah Pendidikan Teknik dan Kejuruan di Indonesia. Bandung: PT. Remaja Rosda Karya, 2002.

12. A. Yogaswara, "Kurikulum SMK Edisi tahun 2004 Bagian Pertama - Kurikulum SMK Panca Bhakti," Kurikulum SMK Panca Bhakti, n.d. https://sites.google.com/site/kurikulumpabha/kurikulum-smk-edisi-tahun-2004-bagian-pertama (accessed Sep. 08, 2021).

13. W. R. Borg, M. D. Gall, and J. P. Gall, Educational Research: An Introduction, 8th Edition. New York: Pearson, 2007.

14. N. S. Sukmadinata, Metode Penelitian Pendidikan. Bandung: Remaja Rosdakarya, 2011.

15. Sugiyono, Metode Penelitian Kuantitatif Kualitatif dan R\&D. Bandung: Alfabeta, 2010.

16. S. Akbar and H. Sriwiyana, Pengembangan Kurikulum dan Pembelajaran Ilmu Pengetahuan Sosial, 2nd Ed. Yogyakarta: Syaamil Cipta Media, 2011.

17. Hobri, Metodologi Penelitian Pe-ngembangan (Aplikasi pada Penelitian Pendidikan Matematika). Jember: Pena Salsabila, 2010.

18. Nurdin, "Model Pembelajaran Matematika yang Membutuhkan Kemampuan Metakognitif untuk Menguasai Bahan Ajar," Universitas Negeri Surabaya, Surabaya, 2007. 